\title{
DIRASAH
}

Volume 2, Number 2, Agustus 2019

p-ISSN: 2615-0212 | e-ISSN: 2621-2838

https://ejournal.iaifa.ac.id/index.php/dirasah

\begin{tabular}{|c|c|c|}
\hline Accepted: & Revised: & Published: \\
April 2019 & Juni 2019 & Agustus 2019 \\
\hline
\end{tabular}

\section{Birokrasi, Perilaku, dan Budaya Organisasi dalam Pendidikan Islam}

\author{
Ainur Rofiq \\ Institut Agama Islam Faqih Asy'ari Kediri, Indonesia \\ e-mail:ainur7682@gmail.com
}

\begin{abstract}
In the educational institution, organization is very important to increase the process and function of education. The man who has much knowledge in the organization, it will make wide knowledge and strong personality. The main purpose of bureacracy is to give servise for public easy and fluently. In the education perspective, bureacracy has a high goal to increase educational quality easy. When the educational institution was able to good, the process and educational function make maximum. Behaviour organization is science which studies about human behaviour. It has connection between human behaviour and organization. the organizational culture and education have relationship strongly. The educational concept has raised of human level as high creature, which has ability to create value and function of culture. The organizational culture can effect a new positive things in the education. It come from outside interaction. So, it will be a new culture in the education, especially to increase educational institution
\end{abstract}

Keywords: Bureacracy, Behaviour Organization, and Culture Organization 


\section{Pendahuluan}

Dalam dunia pendidikan, sebuah organisasi sangat diperlukan dalam rangka memperlancar fungsi dan proses pendidikan. Pengalaman orang dalam organisasi akan membentuk dan membentuk kembali diri mereka sehingga pada akhirnya akan membentuk komitmen emosional dan model mental yang berakar amat dalam yang membimbing perilaku setiap orang. Dalam menjalankan fungsi organisasi pendidikan tidaklah dapat dipisahkan dengan birokrasi. Pada dasarnya, birokrasi ini hakikatnya adalah salah satu perangkat yang fungsinya untuk memudahkan pelayanan publik. Birokrasi digunakan untuk dapat membantu mempermudah dalam memberikan layanan pendidikan yang pasti akan mempengaruhi dalam upaya peningkatan mutu pendidikan.

Birokrasi merupakan instrumen pembangunan pendidikan. Kekuatan birokrasi Indonesia sebetulnya bisa menjadi mesin penggerak yang luar biasa apabila mampu didayagunakan untuk memajukan kesejahteraan rakyat. Jika birokrasi dijalankan dengan benar, konsisten dan bertanggungjawab, maka kualitas pendidikan akan maju. Singapura, Malaysia dan Thailand merupakan contoh nyata negara yang menerapkan birokrasi dengan baik, sehingga pendidikan mereka mempunyai kualitas lebih baik dikarenakan birokrasinya yang profesional, tegas dan efisien.

\section{Pembahasan}

\section{Pengertian birokrasi}

Birokrasi berasal dari kata bureaucracy (bahasa inggris bureau + cracy), diartikan sebagai suatu organisasi yang memiliki rantai komando dengan bentuk piramida, dimana lebih banyak orang berada ditingkat bawah dari pada tingkat atas, biasanya ditemui pada instansi yang sifatnya administratif maupun militer. Birokrasi yang berarti kekuasaan, ditegaskan lagi oleh Albrow bahwa birokrasi adalah suatu badan administratif tentang pejabat yang diangkat sesuai prosedur administrasi yang mampu membedakan hal-hal sepele tetapi penting karena akan menjadi dasar analisis pemikiran sosiologis untuk melakukan tindakan dan analisis kebijakan. ${ }^{1}$ Menurut Weber, bahwa kelebihan birokrasi antara lain:

1. Cocok dengan budaya Indonesia yang paternalistik

2. Dapat menstabilkan kesatuan dan persatuan bangsa

\footnotetext{
${ }^{1}$ Syaiful Sagala, Administrasi Pendidikan Kontemporer (Bandung: CV Alfabeta, 2008), 61.
} 
3. Ketepatan, kejelasan, kontinuitas, keseragaman memudahkan kontrol dan kepatuhan pegawai.

Menurut Husaini birokrasi berkembang secara berlebihan karena :

1. Lemahnya kontrol.

2. Ambisi berlebihan untuk menambah pemasukan daerah.

3. Adanya unjuk kekuasaan pejabat bahwa dirinya harus dianggap penting, sehingga segala sesuatunya harus melalui persetujuannya.

4. Memang dikondisikan untuk membuka peluang pungutan liar, kolusi, dan korupsi. $^{2}$

Begitupun dengan pendidikan agama, seperti perguruan tinggi Islam baik negeri/swasta, Madrasah Aliyah, pondok pesantren, atau madrasah, berada dalam naungan departemen agama sebagai pemegang birokrasi dan menteri agama sebagai pemimpin birokrasi tertinggi di departemen agama. Sebagai birokrasi, departemen agama yang mengatur semua yang berkaitan dengan sistem pemerintahan dalam bidang keagamaan. Berikut adalah hierarki departemen agama beserta yang melingkupinya.

Dari hierarki birokrasi (gambar 1), Menteri Agama dibantu oleh Staf Khusus Menteri Agama dan Staf Ahli Menteri Agama. Kemudian di bawahnya ada Sekertaris Jenderal dan Inspektur Jenderal, kemudian di bawahnya ada Dirjen Bimbingan Masyarakat 5/lima agama, kemudian di bawahnya lagi ada kantor wilayah kemenag/tingkat provinsi dan disusul kantor kementerian agama kota/kabupaten.

Sementara itu birokrasi pendidikan adalah penggunaan praktik-praktik birokrasi dalam pendidikan. Sekolah sebagai organisasi di dalamnya terhimpun kelompok-kelompok manusia yang masing-masing baik secara perseorangan maupun kelompok melakukan hubungan kerja sama untuk mencapai tujuan. Kelompok-kelompok manusia yang dimaksud, tidak lain adalah sumber daya manusia yang terdiri dari Kepala Sekolah, guru-guru, tenaga administrasi/staf, kelompok peserta didik atau siswa dan kelompok orang tua siswa. ${ }^{3}$

Pada birokrasi pendidikan sekolah, ada pembagian tugas-tugas untuk mendukung agar proses interaksi antar manusia dapat dilaksanakan dengan baik. Pembagian tugas dilaksanakan dengan tegas dan sebaik-baiknya, sehingga

2 Husaini Usman. Manajemen, Teori, Praktik, dan Riset Pendidikan (Jakarta: Bumi Aksara, 2006), 85.

3 Wahyo Sumidjo, Kepemimpinan Kepala Sekolah Tinjauan Teoritik dan Permasalahanya (Jakarta: PT Raja Grafindo Persada, 2003), 144.

Dirasah, Vol. 2, No. 2, Agustus 2019 
masing-masing kelompok dan orang-orang dengan jelas melakukan tugas apa, kapan, dan bagaimana dilakukan. Misalnya pembagian guru bidang study( mata pelajaran, pembimbing), dilingkungan staf ada tugas-tugas yang khusus dalam hal keuangan, kepegawaian, perlengkapan dan sebagainya. Seluruh siswa sebagai peserta didik pun dikelompok-kelompokkan ke dalam siswa kelas I, II, dan III. Ada kelompok siswa kategori berprestasi, bermasalah, dan sebagainya. Dalam hal ini, penulis meneliti birokrasi di MA Sunni Darussalam yang terletak di Dukuh Tempelsasi Banjeng Maguwoharjo Depok Sleman Yokyakarta. MA Darussalam adalah salah satu unit pendidikan formal yang berada di bawah naungan yayasan Pondok Pesantren. Pesantren ini didirikan oleh almarhum Prof Dr.KH. Moh Tolchah Mansoer, SH, yang notabene pendiri IPNU (Ikatan Pelajar Nahdlatul Ulama).

\section{Gambar 1 Hierarki Birokrasi}

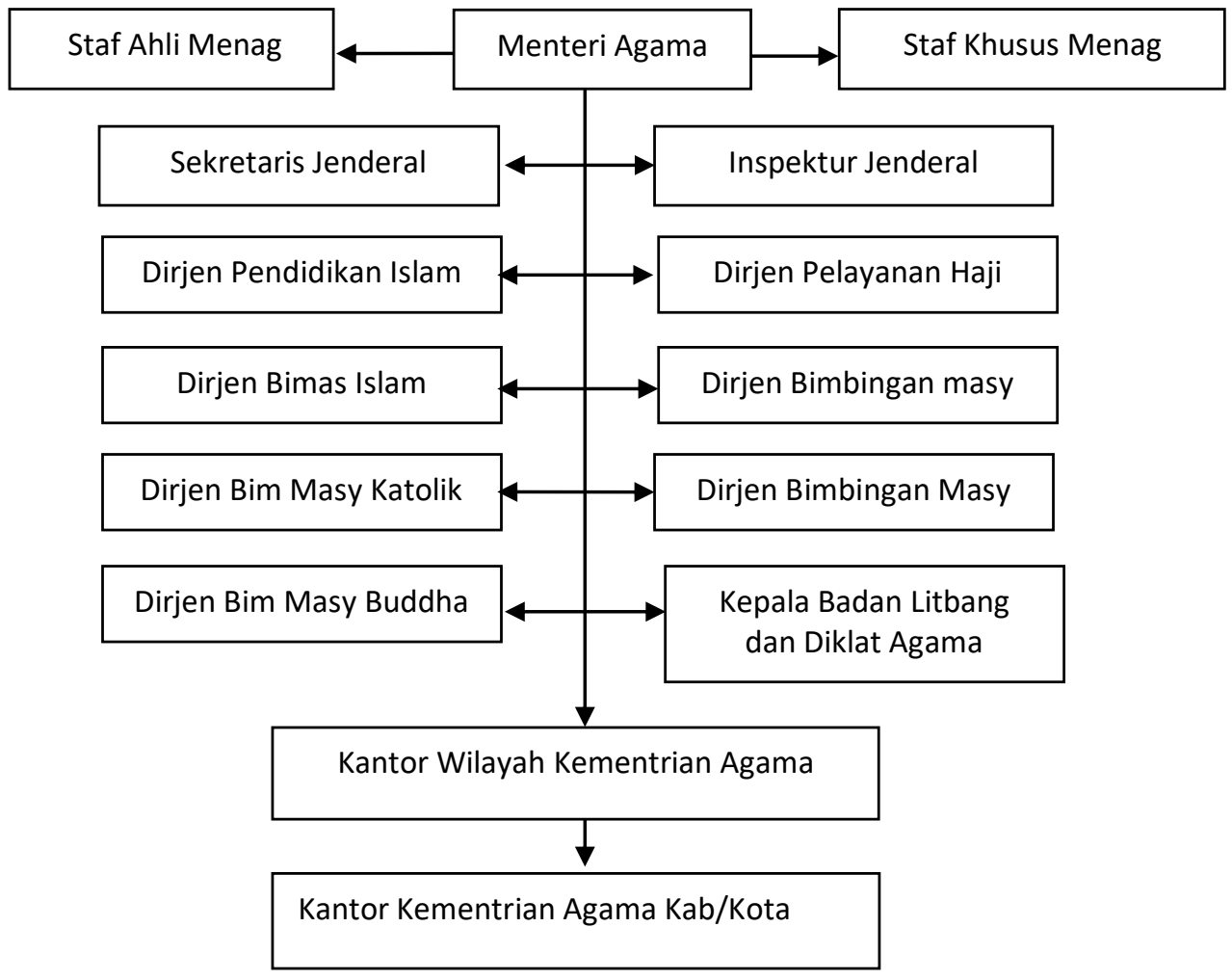

Dirasah, Vol. 2, No. 2, Agustus 2019 
Pada gambar 2 adalah birokrasi atau struktur organisasi yang berada di MA Darussalam Depok Sleman Yokyakarta, Birokrasi pendidikan sekolah yang diterapkan di MA Darussalam secara pengelolaan diserahkan kepada Kepala Sekolah, namun secara kelembagaan dipegang ketua yayasan. ${ }^{4}$ Menurut wawancara yang kami lakukan dengan Walidi S.HI, bahwa fungsi dari setiap waka belum bisa berjalan dengan baik dan kurang maksimal. Misalnya untuk waka kurikulum, kurangnya konsolidasi dengan waka yang lain dalam menata kurikulum untuk proses pembelajaran, dan waka kurikulum hanya akan berfungsi ketika akan ada akreditasi sekolah. ${ }^{5}$

Gambar 2. Struktur Organisasi MA Darussalam Depok Sleman Yokyakarta

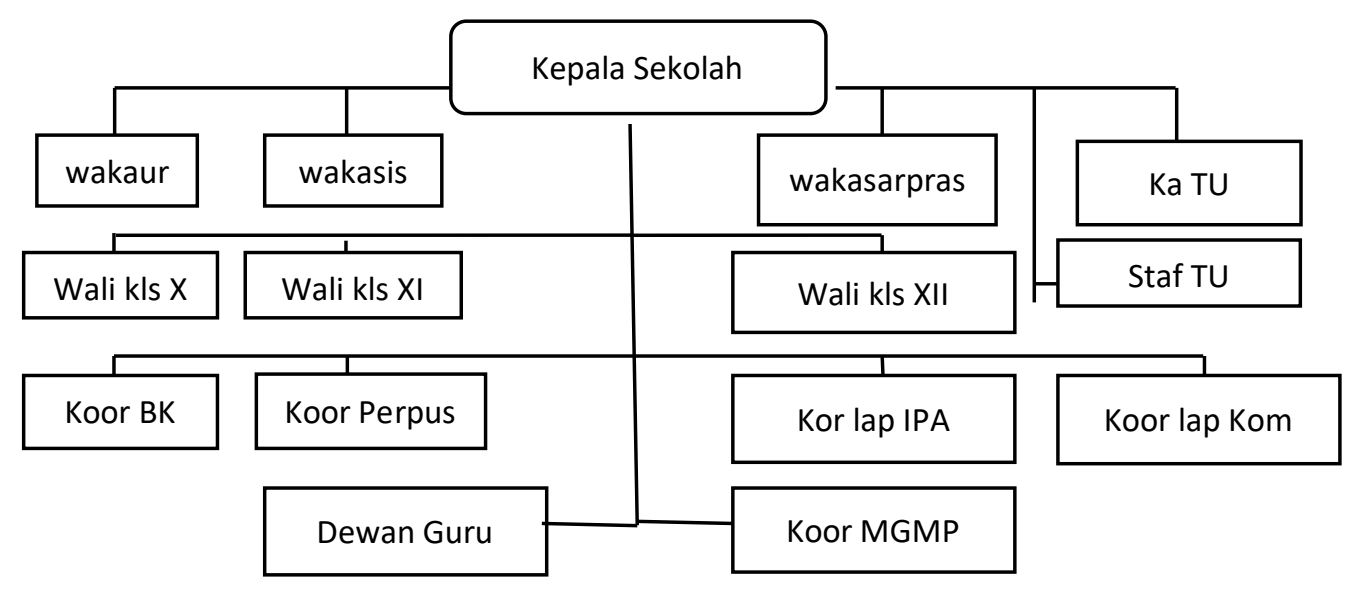

Untuk waka kesiswaan, Walidi menuturkan bahwa untuk waka kesiswaan berjalan dengan baik. Hal ini lebih disebabkan oleh sosok pak Tabiul Huda yang menjabat sebagai wakasis. Dengan profil yang disegani oleh peserta didik di MA Darussalam, menjadikan kegiatan yang berkaitan dengan kesiswaan bisa di kendalikan dengan baik. Untuk waka sarana dan prasarana, juga kurang terjadi konsolidasi dengan baik dengan kepala sekolah, dalam artian waka sarpras tidak tidak terlalu berfungsi/berjalan dengan maksimal, kecuali kalau ada hal/perkara

\footnotetext{
${ }^{4}$ Wawancara dengan Walidi, Wakil Kepala Sekolah MA Darussalam Depok Sleman Yokyakarta, pada tanggal 10 Mei 2018.

${ }^{5}$ Wawancara dengan Walidi, Wakil Kepala Sekolah MA Darussalam Depok Sleman Yokyakarta, pada tanggal 23 Mei 2018.
}

Dirasah, Vol. 2, No. 2, Agustus 2019 
yang dianggap penting. Untuk kepala TU berjalan sesuai dengan fungsinya, dalam artian dalam keseharian mengerjakan fungsi administrasi dengan baik.

Sedangkan untuk staf TU, disamping membantu tugas kepala TU dalam menyelesaikan tugas administratif, juga mengganti guru yang tidak bisa datang mengajar. Menurut penuturan kepala sekolah, wali kelas untuk setiap kelasnya sudah melaksanakan tugasnya dengan baik. Hubungan antara wali kelas dengan peserta didik terjalin seperti orang tua dan anak, sehingga terjadi komunikasi yang harmonis. ${ }^{6}$ Berdasarkan wawancara dengan Aziz Ahmad M.Hum, salah satu pendidik senior menuturkan koordinasi bimbingan konseling/BK berjalan dengan baik dan optimal. Untuk koordinasi perpustakaan, juga berjalan dengan baik. Minat peserta didik dalam mengembangkan kemampuan mereka lewat beberapa kegiatan seperti menulis di jurnal/mading, membuat fungsi koordinator perpustakaan hidup.

Ada yang menarik yang menjadi perhatian kami sebagai peneliti, yaitu keberadaan laboratorium IPA yang tidak berfungsi secara maksimal dikarenakan di MA Darussalam tidak ada jurusan IPA. Masih menurut Aziz Ahmad M.Hum, keberadaan lap IPA ini hanya untuk kelas 1 Aliyah, karena ada 1mata pelajaran IPA yang membutuhkan untuk praktik di lab. ${ }^{7}$ Sehingga bisa dikatakan bahwa guru koordinator lab IPA seperti mati suri, dikarenakan jarang sekali lab difungsikan sebagaimana mestinya, itu pun ketika kelas 1 Aliyah menggunakan jasa lab untuk pelajaran IPA. Untuk guru bidang koordinator laboratorium komputer menjalankan tugas dengan baik. Dikarenakan salah satu kegiatan ekstrakurikuler adalah mata pelajaran komputer. Aziz Ahmad juga memberikan penjelasan kepada kami bahwa untuk koordinator MGMP kurang berjalan dengan baik. Hal ini lebih disebabkan karena guru-guru yang mengajar rata-rata hanya mempunyai jam terbang mengajar yang sedikit. Di samping itu juga para guru yang notabene masih banyak yang kuliah, jadi mereka tidak terlalu memikirkan dan kurang konsentrasi ke ranah pendidikan. Sedangkan untuk pembagian tugas antar individu (guru) berjalan sesuai dengan fungsinya masingmasing. Namun masih ada fungsi ganda dalam hal pengajaran, misalnya bendahara yang sambil merangkap menjadi tenaga pengajar, tenaga pengajar

\footnotetext{
${ }^{6}$ Wawancara dengan Walidi, Wakil Kepala Sekolah MA Darussalam Depok Sleman Yokyakarta, pada tanggal 10 Mei 2018.

${ }^{7}$ Wawancara dengan Aziz Ahmad, pendiddik di MA Darussalam Depok Sleman Yokyakarta, pada tanggal 23 Mei 2018.
} 
yang notabene sebagian belum s1 dan masih aktif kuliah (semester akhir), menyebabkan proses pembelajaran menjadi kurang efektif.

Mengenai hubungan antar individu dalam artian kepala sekolah dengan guru-guru dan staf berjalan dengan baik, hal ini juga diperkuat hubungan lewat grup WhatsApp. Pada sebuah birokrasi pendidikan juga selalu memiliki serangkaian peraturan yang berperan untuk mengatur proses interaksi. Dalam birokrasi pendidikan sekolah, kegiatan proses interaksi diikat dan diatur dengan serangkaian peraturan sehingga kegiatan atau proses interaksi berjalan dengan teratur, terencana, berkelanjutan, dan terkoordinasi. ${ }^{8}$ Peraturan-peraturan yang berkaitan dengan pelaksanaan pembelajaran, misalnya yang berkaitan dengan pelaksanaan pelajaran yang mencakup program, pelaksanaan, dan penilaian.

Di MA Darussalam hal ini berjalan sesuai dengan baik. Program yang di antaranya lama pendidikan dan susunan program kurikulum tercover sesuai yang diharapkan. Begitupun dengan kegiatan pengajaran, pendekatan dan strategi belajar mengajar berjalan sesuai koridor pada umumnya. Dalam birokrasi pendidikan, hubungan struktur dalam organisasi sekolah dapat dilihat dari keberadaan kepala sekolah sebagai pemimpin yang diberi tugas memimpin sekolah dengan kelompok guru dan tenaga fungsional yang lain. Kedudukan Kepala sekolah sebagai pemimpin formal bersifat legitimatif, artinya dikokohkan dengan kekuatan hukum yang tertulis.

Dan tidak menutup kemungkinan dalam kelompok guru, staf, siswa, atau orang tua siswa terdapat hubungan yang bersifat hierarki, ada yang mendapat tugas dan kepercayaan berperan sebagai pemimpin meskipun tidak bersifat formal.

Pada MA Darussalam hal ini juga berlaku, dalam artian ada seorang guru senior yang bernama Tabiul Huda S.Hum, secara informal merangkap sebagai ketua satuan kelompok guru, bahkan ketika kepala sekolah ada urusan keluar, orang ini sering di beri wewenang menggantikan tugasnya sebagai kepala sekolah.

Dalam birokrasi pendidikan sekolah, sistem komunikasi dalam pendidikan diterapkan agar komunikasi yang melibatkan berbagai macam guru, staf, dan orang tua siswa berjalan tertib mendukung terwujudnya tujuan proses belajar. Dalam birokrasi pendidikan, juga dilaksanakan adanya satu sistem insentif tertentu. Tujuannya adalah untuk merangsang dan membangkitkan seluruh

\footnotetext{
${ }^{8}$ Wahyo Sumidjo, Kepemimpinan Kepala Sekolah., 145
}

Dirasah, Vol. 2, No. 2, Agustus 2019 
komponen yang ada agar melakukan tugas dengan semaksimal mungkin. Insentif tidak terbatas hanya pada gaji, namun dapat diwujudkan dalam berbagai bentuk seperti suasana kerja yang mendukung, sarana fasilitas, kesejahteraan, penghargaan, dan sebagainya.

Di MA Darussalam, hal ini berjalan dengan baik, sarana dan fasilitas terbilang sudah memadai, dengan menempati gedung baru berlantai 3 beserta sarana pendukungnya. Di MA Darussalam sistem komunikasi antara kepala sekolah dan bawahan, guru dengan guru yang lain, berjalan dengan baik. Masalah insentif masih menjadi kendala meskipun tidak terlalu urgen untuk dimunculkan ke permukaan, di MA Darussalam untuk insentif para guru terbilang masih sedikit dibanding dengan lembaga pendidikan yang lain. Ini yang menyebabkan sedikit banyak adanya pengaruh pada proses pembelajaran peserta didik. ${ }^{9}$

Pada umumnya, ada hal yang menyebabkan sikap negatif terhadap birokrasi pendidikan adalah : peraturan-peraturan yang berjalan lama cenderung untuk dipaksakan atau ditekankan dengan berlebihan, peraturan dan prosedur yang dilaksanakan dengan cara-cara yang tidak fleksibel, lamban dan berbelitbelit. Masalah birokrasi pendidikan lainnya adalah penempatan dan formasi pada pemerintah provinsi dan kabupaten/kota yang tidak jelas dan kabur. ${ }^{10}$

\section{Pengertian perilaku organisasi dan ruang lingkupnya dalam pendidikan Islam}

Untuk dapat memahami mengenai perilaku organisasi secara tepat, terlebih dahulu harus memahami beberapa konsep mendasar terkait dengan perilaku organisasi, yaitu konsep perilaku dan organisasi ${ }^{11}$ Pandangan lama tentang organisasi mengungkapkan bahwa organisasi merupakan suatu wadah interaksi orang-orang untuk mencapai suatu tujuan. Pandangan terkini organisasi dipandang sebagai suatu hal yang lebih dinamis dari pada suatu wadah. Organisasi dipandang sebagai satuan sistem sosial untuk mencapai tujuan bersama melalui usaha bersama atau kelompok.

Ruang lingkup perilaku organisasi meliputi bagaimana memahami orangorang dalam satuan sistem sosial, mengelola, dan memprediksi bagaimana mereka dapat bekerja secara efektif. Perilaku organisasi adalah suatu studi yang

\footnotetext{
${ }^{9}$ Wawancara dengan Aziz Ahmad, Guru MA Darussalam Depok Yokyakarta, pada tanggal 10 Mei 2018.

${ }^{10}$ Syaiful Sagala, Administrasi Pendidikan Kontemporer., 41.

${ }^{11}$ Cecep Triatna, Perilaku Organisasi Dalam Pendidikan (Bandung: Remaja Rosdakarya, 2015), 2.
} 
menyangkut aspek-aspek tingkah laku manusia dalam suatu organisasi atau suatu kelompok tertentu. Ia meliputi aspek yang ditimbulkan dari pengaruh organisasi terhadap manusia demikian pula aspek yang ditimbulkan dari pengaruh manusia terhadap organisasi. Tujuan praktis dari penelaahan studi ini adalah untuk mendeterminasi bagaimanakah perilaku manusia itu mempengaruhi usaha pencapaian tujuan-tujuan organisasi. ${ }^{12}$

Perilaku organisasi sering disingkat sebagai OB (Organisational Behavior) adalah studi mengenai perilaku manusia, mengenai titik temu antara perilaku manusia dan organisasi, serta organisasi itu sendiri. ${ }^{13}$ Di samping itu, perilaku organisasi menerapkan pengetahuan yang diperoleh mengenai perorangan, kelompok dan efek dari struktur pada perilaku, agar organisasi bekerja dengan lebih efektif.

Perilaku organisasi, sesungguhnya terbentuk dari perilaku-perilaku individu yang terdapat dalam organisasi tersebut. Pengkajian masalah perilaku organisasi jelas akan meliputi atau menyangkut pembahasan mengenai perilaku individu. Dengan demikian dapat dilihat bahwa ruang lingkup kajian ilmu perilaku organisasi hanya terbatas pada dimensi internal dari suatu organisasi. Dalam kaitan ini, aspek-aspek yang menjadi unsur-unsur, komponen atau sub sistem dari ilmu perilaku organisasi antara lain adalah: motivasi dan kepemimpinan, stres dan atau konflik, pembinaan karier, masalah sistem imbalan, hubungan komunikasi, pemecahan masalah dan pengambilan keputusan, produktivitas dan atau kinerja (performance), kepuasan, pembinaan dan pengembangan organisasi (organizational development).

\section{Motivasi dan kepemimpinan}

Motivasi tidak dapat diamati secara langsung, tetapi dapat diinterpretasikan dari tingkah lakunya. Motivasi dapat dipandang sebagai perubahan energi dalam diri seseorang yang ditandai dengan munculnya feeling dan didahului dengan tanggapan terhadap adanya tujuan. Motivasi diartikan sebagai keadaan dalam pribadi seseorang yang mendorong keinginan individu untuk melakukan kegiatan-kegiatan tertentu guna mencapai tujuan. Motivasi yang ada pada seseorang merupakan kekuatan pendorong yang akan mewujudkan suatu perilaku

\footnotetext{
${ }^{12}$ Miftah Toha, Perilaku Organisasi Konsep Dasar dan Aplikasinya (Jakarta: PT Raja Grafindo Persada, 2007), 5.

${ }^{13}$ Gregory Moorhead dan Ricky W. Griffin, Perilaku Organisasi Manajemen Sumber Daya Manusia (Tangerang: Salemba Empat, 2010), 3.
}

Dirasah, Vol. 2, No. 2, Agustus 2019 
guna mencapai tujuan kepuasan dirinya. Motivasi merupakan hasrat dalam seseorang yang menyebabkan orang tersebut melakukan tindakan untuk mencapai tujuan. Motivasi ini sangat penting, karena dengan adanya motivasi diharapkan setiap individu memiliki semangat untuk mencapai produktivitas kerja yang tinggi.

Dalam lembaga pendidikan MA Darussalam, sebagaimana disampaikan oleh salah satu pengajarnya bahwa pemberian motivasi kepala sekolahnya terhadap para anggotanya tidak efektif . Kepala Sekolah sering memotivasi bahwa profesi mengajar diantaranya pengabdian dan mengharap ridho dari Allah SWT. Hal ini tampak pada kurangnya penghargaan dan reward bagi pengajar yang menjalankan pembelajaran dengan baik. Kondisi ini sebagaimana hasil pengamatan bahwa ada beberapa pengajar yang terlambat masuk kelas dan tidak mempersiapkan perangkat pembelajaran sebelumnya.

Berdasarkan hasil wawancara bahwa alasan situasi ini adalah karena disamping gaji yang diberikan lumayan sedikit, juga adanya tugas yang harus ditanggung oleh para pengajar. Dengan demikian lambat laun pengajar yang aktif dan rutin akan mengikuti irama yang berjalan, sehingga tidak optimalah proses pembelajaran. $^{14}$

Seorang pemimpin yang dapat memberi inspirasi, membujuk, mempengaruhi, dan memotivasi dapat memicu perubahan yang berguna. Menciptakan perubahan adalah salah satu tujuan kepemimpinan. Apabila pendekatan dalam pemberian motivasi ditekankan pada imbalan atau reward (baik ekonomis maupun non ekonomis), berarti telah melakukan hal yang positif. ${ }^{15}$

\section{Stres dan konflik}

Stres dan konflik merupakan suatu yang tidak dapat dihindarkan dalam kehidupan organisasi, bahkan stres dan konflik selalu hadir dalam setiap hubungan kerja antar individu dan kelompok. Stres dan konflik dapat berdampak positif ataupun negatif bergantung pada pendekatan manajemen yang dilakukan. Sedangkan menurut istilah dan pengertian umum bahwa stress adalah suatu gangguan pada tubuh dan pikiran yang disebabkan oleh perubahan dan tuntutan

\footnotetext{
${ }^{14}$ Wawancara dengan Hamdani, Guru MA Sunni Darussalam Depok Yokyakarta, pada tanggal 10 Mei 2018.

${ }^{15}$ Husaini Usman. Manajemen, Teori, Praktik .,149
}

Dirasah, Vol. 2, No. 2, Agustus 2019 
kehidupan. Stress merupakan pengalaman internal yang menciptakan ketidakseimbangan fisik dan psikis dalam diri seseorang sebagai akibat dari faktor lingkungan eksternal, lembaga, organisasi atau orang lain. ${ }^{16}$

Bila dengan menggunakan metode-metode tertentu konflik masih belum dapat diselesaikan, manajer bisa menggunakan tenaga eksternal sebagai penengah atau mediator. Hal ini karena manajemen tidak selamanya dapat menggunakan kekuasaan untuk memaksakan atau mengatasi konflik yang ada. ${ }^{17}$ Menurut wawancara yang kami lakukan di MA Darussalam, tidak ada konflik dan stres yang berarti di lingkungan pendidikan tersebut. Semua permasalahan yang menjadikan beban dan ketidakharmonisan bisa diselesaikan dengan sistem harmonis, kekeluargaan, dan familiar.

\section{Pembinaan karier}

Pembinaan karir sangat penting dilakukan oleh pemimpin kepada anggotanya untuk meningkatkan potensi dirinya agar bisa mengembangkan prestasi kerjanya, sehingga tujuan organisasi bisa tercapai. Pembinaan karier bersifat bimbingan pada perubahan tugas yang diberikan karena penyegaran maupun prestasi yang telah dicapai. Pembinaan karier harus dilakukan evaluasi dan dimonitor agar penempatannya tepat sasaran.

\section{Imbalan}

Pemberian imbalan harus mempertimbangkan atau memprioritaskan tingkat kesulitan dan pengaruh posisi kerja, kebutuhan individu pekerja, produktifitasnya dalam arti semakin produktif semakin besar pendapatannya, kesesuaian dengan UMR, kesepakatan dengan pihak pegawai, serta jika pekerja itu dari lembaga penyalur tenaga kerja maka harus diperhatikan tingkat nominal yang telah disepakati dengan serikat pekerja.

Imbalan tentunya akan diperoleh setelah melakukan suatu pekerjaan, imbalan ini tentunya mempertimbangkan analisis dan evaluasi jabatan yang dibutuhkan sehingga penentuan nominalnya sesuai dengan porsi kerja dan kebutuhan pribadi yang memadai. Pemandangan yang ada di MA Darussalam, pengajar cenderung tidak mendapatkan kenaikan gaji disetiap tahunya. Hal ini

\footnotetext{
${ }^{16}$ Mulyasa, Manajemen Kependidikan Kepala Sekolah (Jakarta: Bumi Aksara, 2011), 274.

${ }^{17}$ Didin Kurniadin dan Imam Mahalli, Manajemen Pendidikan, Konsep dan Prinsip Pengelolaan (Yokyakarta: ar Ruzz Media, 2012), 273.
}

Dirasah, Vol. 2, No. 2, Agustus 2019 
yang menyebabkan sebagian pengajar harus meluangkan waktu untuk mencari pekerjaan sampingan. Dan tidak jarang ada beberapa guru yang memutuskan untuk keluar dari profesi mengajar, ini lebih pada sosok guru laki-laki yang mempunyai tanggung jawab ganda. Oleh karena itu, peran pemimpin juga penting dalam memikirkan porsi gaji bawahannya termasuk pembagian tugastugasnya

\section{Hubungan komunikasi}

Komunikasi merupakan kegiatan yang sangat penting dalam organisasi. Jika dua orang atau lebih bekerja sama maka perlu adanya komunikasi antar mereka. Makin baik komunikasi mereka makin baik pula kemungkinan kerja sama mereka dan hendaknya dalam berkomunikasi harus menggunakan tutur bahasa yang baik. Komunikasi berkaitan dengan interaksi antar dua manusia atau lebih yang berfungsi menyampaikan ide, gagasan dan lainnya agar tercipta hubungan komunikasi yang baik. Komunikasi yang ada di MA Darussalam komunikasi antara atasan ke bawahan bagus, namun di satu sisi, yaitu kurang begitu bagus, terutama dalam hal mengenai kebijakan dan mengenai keputusan karena kurang intensnya rapat bulanan yang hanya terkesan angin-anginan, dalam artian kalau hanya mau ada hal yang dianggap penting, baru diadakan rapat.

\section{Produktifitas atau kinerja (performance)}

Performance atau kinerja adalah pencapaian hasil kerja yang sesuai dengan perencanaannya atau target yang sudah ditentukan baik yang berupa fisik atau non fisik. Produktivitas berbasis aktifitas kerja yang menjamin bahwa anggota organisasi telah menjalankan dengan baik. Secara alami, para pengajar telah menjalankan peran dan tugasnya baik mengajar dan memonitor perkembangan peserta didik. Dikarenakan menurut beberapa pengajar bahwa penghargaan tidak didapatkan, maka tingkat kinerjanya belum maksimal.

\section{Kepuasaan}

Kepuasan kerja tercermin dalam dunia kerja dimana baik pekerja maupun pemilik pekerjaan sama-sama terpenuhi kebutuhannya. Kepuasan kerja adalah suasana psikologis tentang perasaan menyenangkan atau tidak menyenangkan terhadap pekerjaan mereka Sumber kepuasan kerja terdiri dari pekerjaan yang 
menantang, imbalan yang sesuai, kondisi lingkungan kerja yang mendukung dan rekan kerja yang mendukung.

Adakalanya kepuasan kerja tercukupi secara finansial ataupun kenyamanan bekerja, namun terkadang menjadi tidak puas manakala jadwal liburan tidak terwujud sehingga dapat menurunkan prestasi kerja pegawai. Para guru di MA Darussalam rata-rata menyatakan tingkat kepuasan dalam hal mengajar, karena mereka tidak terbebani dengan hal-hal yang berat, ketidakpuasan pengajar lebih pada fee yang diberikan.

\section{Pengambilan keputusan dan pemecahan masalah}

Pengambilan keputusan ialah proses memilih sejumlah alternatif. Pengambilan keputusan penting bagi administrator pendidikan karena proses pengambilan keputusan mempunyai peran penting dalam memotivasi, kepemimpinan, komunikasi, koordinasi dan perubahan organisasi. Keputusan yang diambil berpengaruh terhadap pelanggan pendidikan terutama peserta didik. Oleh karena itu, setiap administrator pendidikan harus memiliki keterampilan mengambil keputusan secara tepat, cepat, efektif dan efisien.

Pemecahan masalah merupakan suatu proses pengamatan dan pengenalan serta usaha mengurangi perbedaan antara keadaan sekarang dengan keadaan yang akan datang yang diharapkan. Kemampuan mengambil keputusan harus dimiliki oleh pimpinan sebagai pemilik kebijakan, demikian juga pemecahan masalah yang terjadi baik secara intern maupun ekstern. Dalam mengambil keputusan hendaknya mempertimbangkan beberapa aspek sehingga hasil keputusannya tepat, valid, dan tidak timpang sebelah.

Pengambilan keputusan yang ada pada MA Darussalam terkadang dilakukan secara sepihak oleh kepala sekolah, tanpa berkoordinasi terlebih dahulu pada bawahanya/guru-guru, misalnya ketika ada kegiatan yang sifatnya mendadak. Dan disisi lain kepala sekolah biasanya berkoordinasi dengan guruguru dalam pengambilan keputusan dan pemecahan masalah.

\section{Pengembangan organisasi}

Pengembangan organisasi merupakan tindakan beralihnya sesuatu organisasi dari kondisi yang berlaku kini ke kondisi masa yang akan datang yang diinginkan guna meningkatkan efektivitasnya. Peralihan tersebut bukan berarti merubah semua tatanan yang berlaku, melainkan mengembangkan kondisi yang 
stagnan menjadi lebih dinamis serta beralih menuju kepada kemajuan. Globalisasi sangat mempengaruhi bidang ekonomi, informasi, teknologi dan budaya. Semua bidang tersebut memerlukan pengelolaan organisasi yang profesional.

\section{Budaya organisasi dan ruang lingkupnya dalam pendidikan Islam}

Dalam kehidupan masyarakat sehari-hari tidak terlepas dari ikatan budaya yang diciptakan. Ikatan budaya tercipta oleh masyarakat yang bersangkutan, baik dalam keluarga, organisasi, bisnis maupun bangsa. Dalam definisinnya, budaya organisasi merupakan nilai dasar organisasi berupa keyakinan, norma-norma, dan cara belajar orang-orang dalam organisasi yang merupakan perekat dan ciri khas organisasi yang bisa membedakan dengan organisasi lainnya dan hal tersebut juga ditularkan kepada setiap personel baru dalam organisasi. ${ }^{18}$ Budaya membedakan masyarakat satu dengan yang lain dalam cara berinteraksi dan bertindak menyelesaikan suatu pekerjaan. Budaya mengikat anggota kelompok masyarakat menjadi satu kesatuan pandangan yang menciptakan keseragaman berperilaku atau bertindak. Sewaktu para anggota organisasi berinteraksi, nilai, norma, kepercayaan, dan cara berfikir bersama pun muncul. Orientasi bersama ini membentuk budaya organisasi. ${ }^{19}$ Budaya organisasional membedakan satu organisasi dengan organisasi lainnya dan membekali para anggota dengan rasa akan identitas organisasioanl. Budaya membekali para anggota dengan komitmen pada kepercayaan dan nilai diluar dirinya sendiri, individu menginduk ke dalam kelompok yang lebih besar dari dirinya sendiri. Ketika budayanya kuat, maka begitu jugalah dengan identifikasinya dengan kelompok dan pengaruh. Budaya mempresentasikan bagian emosional organisasi yang tak tertulis. Seiring dengan bergulirnya waktu, budaya pasti terbentuk dalam organisasi dan dapat pula dirasakan manfaatnya dalam memberi kontribusi bagi efektivitas organisasi secara keseluruhan.

Antara pendidikan dan budaya organisasi terdapat hubungan yang sangat erat dalam arti keduanya dengan suatu hal sama yaitu nilai-nilai. Pendidikan selalu berkaitan dengan manusia, sedang manusia selalu menjadi anggota masyarakat dan mendukung budaya tertentu. Konsep pendidikan mengangkat

\footnotetext{
${ }^{18}$ Cecep Triatna, Perilaku Organisasi dalam., 174.

19 Wayne K.Hoy dan Cecil G. Miskel, Administrasi Pendidikan Teori, Riset, dan Praktik, terj Educational Administration. ( Yokyakarta: Pustaka Pelajar, 2014), 40.
}

Dirasah, Vol. 2, No. 2, Agustus 2019 
derajat manusia sebagai makhluk budaya yaitu makhluk yang mempunyai kemampuan untuk menciptakan nilai budaya dan fungsi budaya serta pendidikan adalah kegiatan melontarkan nilai-nilai.

Dengan adanya budaya di dunia pendidikan, maka timbullah berbagai organisasi, budaya organisasi banyak menimbulkan hal-hal yang masuk dalam dunia pendidikan berbagai interaksi-interaksi dari luar, yang menjadi budaya baru dalam pendidikan, terutama dalam upaya mengembangkan lembaga pendidikan.

Menurut Wirawan budaya organisasi adalah norma, nilai-nilai, asumsi, kepercayaan, filsafat, kebiasaan organisasi, dan sebagainya isi budaya organisasi yang dikembangkan dalam waktu yang lama oleh pendiri, pemimpin, dan anggota organisasi yang disosialisasikan dan diajarkan kepada anggota baru serta diterapkan dalam aktivitas organisasi sehingga mempengaruhi pola pikir, sikap, dan perilaku anggota organisasi dalam memproduksi produk, melayani para konsumen, dan mencapai tujuan. ${ }^{20}$

Budaya organisasi berpengaruh pada perilaku anggota atau individu serta kelompok di dalam suatu organisasi, padahal perilaku ini berpengaruh pula pada pencapaian prestasi tersebut dan sekaligus secara bersama-sama akan berpengaruh pada efektif tidaknya pencapaian tujuan organisasi. Oleh karena itu, secara singkat dapat dikatakan bahwa budaya organisasi berpengaruh pada efektifitas organisasi. ${ }^{21}$

Budaya yang ada di dalam organisasi bisa kuat dan juga bisa lemah. Budaya organisasi dikatakan kuat apabila nilai-nilai, sikap, dan kepercayaan bersama tersebut dipahami serta dianut dengan teguh dan komitmen yang tinggi, sehingga rasa kebersamaan dapat tercipta. Sebaliknya budaya organisasi yang lemah terletak pada kurangnya komitmen anggota/karyawan terhadap nilai-nilai dan kepercayaan terhadap sikap-sikap bersama yang biasa dilakukan atau disepakati. $^{22}$

Pentingnya budaya dalam institusi pendidikan atau sekolah menjadi perhatian pengelola dan pemerhati pendidikan karena budaya sekolah dipandang sebagi hal mendasar dalam kemampuan sekolah untuk membangkitkan dan mempertahankan peningkatan mutu/kualitas sekolah. Selain itu, budaya sekolah

\footnotetext{
${ }^{20}$ Wirawan, Budaya dan Iklim Organisasi (Jakarta: Salemba Barat, 2007), 10.

${ }^{21}$ Uus Ruswadi, Landasan Pendidkan (Bandung: Insan Mandiri, 2008), 78.

${ }^{22}$ Syafarrudin, Manajemen Mutu Terpadu Dalam Pendidikan (Jakarta: Grasindo, 2002), 94.
}

Dirasah, Vol. 2, No. 2, Agustus 2019 
juga terkait dengan budaya kelas-kelas yang ada di sekolah tersebut. Pengembangan budaya sekolah akan melahirkan kemampuan organisasi untuk sukses dalam melakukan suatu perubahan atau merespon suatu perubahan. Budaya organisasi di sekolah dapat menjadikan para pengelola sekolah aktif, kreatif, intelek, adaptif, mampu mengorganisasi diri, dan terus mencari makna dari setiap kegiatan yang dilakukan.

Dalam budaya organisasi, dalam hal ini sekolah dapat dikategorikan sebagai organisasi birokratis yang dicirikan oleh adanya struktur dan pembagian wewenang yang jelas diantara personel sekolah, banyak orang berkomitmen terhadap status mereka dalam hierarki, manajemen, organisasi kepegawaian, politisi, atau terhadap dirinya sendiri sebagai korban. Sedangkan definisi budaya sekolah adalah nilai-nilai dasar sekolah yang merupakan perekat dan ciri khas organisasi yang bisa membedakan antara satu sekolah dengan sekolah yang lainnya juga bisa ditularkan kepada setiap personel baru disekolah.

Budaya sekolah merupakan interaksi dari berbagai elemen sekolah meliputi elemen-elemen jadwal, kurikulum, demografik, dan kebijakan-kebijakan sebagai intaraksi sosial yang terjadi dalam struktur tersebut dan memperlihatkan pandangan dan perasaan sekolah seperti bersahabat, elite, kompetitif, dan lain sebagainnya. Ada enam unsur budaya yang menjadi kajian peneliti budaya organisasi, yaitu : nilai/ritual, kepercayaan/beliefs, kerja/aktifitas, ritual, upacaraupacara, dan objek-objek budaya. Schein menggambarkan unsur budaya organisasi sebagai berikut:

\section{Gambar 3. Unsur Budaya Organisasi}

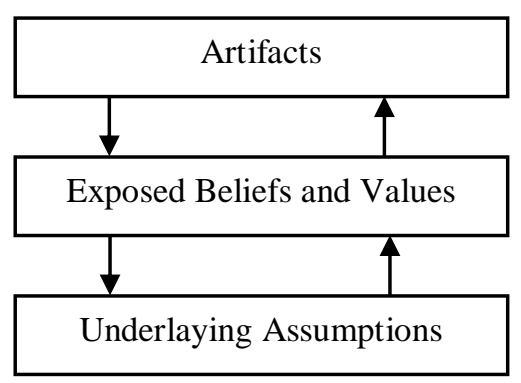

Visible organizational structures, and proceses

Unconscious, taken for granted beliefs, perceptions, thoughts, and feelings 
Artifacts adalah sesuatu yang dimodifikasi oleh manusia untuk mencapai tujuan tertentu. Artifacts merupakan hal yang paling mudah dilihat dan ditangkap saat kita memasuki sebuah organisasi karena berhubungan dengan apa yang kita lihat, kita dengar, dan kita rasakan saat berada di dalamnya. Unsur artifacts adalah struktur dan proses-proses organisasi yang terjadi dalam keseharian. Exposed valued adalah nilai-nilai yang didukung oleh organisasi meliputi strategi, tujuan, dan filosofi dasar organisasi. Sedangkan basic underlaying assumptions adalah asumsi-asumsi yang tersirat yang dipegang bersama oleh setiap anggota organisasi dan menjadi dasar pijakan. ${ }^{23}$

Berdasarkan wawancara dengan Aziz Ahmad, salah satu guru di MA Darussalam menuturkan bahwa budaya membaca yang dimiliki oleh siswa-siswi tersebut termasuk bagus, adanya perpustakaan juga menjadi salah satu pendukung. Namun kebiasaan untuk memasukkan baju bagi siswa laki-laki masih belum optimal, bahkan cenderung tidak ada peringatan ataupun teguran baik dari kepala sekolah maupun pendidik. Berbeda dengan peserta didik yang perempuan, yang notabene bisa dibilang rajin dan rapi dalam berpakaian dan sangat menyadari peraturan yang dibuat oleh pihak sekolahan. Hal yang perlu menjadi perhatian serius adalah tidak adanya waktu belajar malam yang dikarenakan habis dipakai untuk mengaji pada kyai nya.

Kurangnya atau tidak adanya manajemen waktu yang bagus merupakan kendala yang serius bagi peserta didik dalam menyisihkan dan mengatur waktu untuk belajar. Namun untuk kelas 3 aliyah, diberikan waktu yang cukup untuk belajar karena dipandang untuk menghadapi ujian akhir negara. Di MA Darussalam setiap setengah tahun sekali mengadakan seminar atau kajian untuk menambah wawasan keilmuan bagi peserta didik.

Budaya bersih-bersih atau ro'an setiap hari jum'at merupakan pembelajaran atau penanaman nilai-nilai tentang betapa pentingnya menjaga kebersihan lingkungan dan membiasakan pembelajaran untuk hidup bersih.

Dalam Budaya organisasi, di dalamnya terdapat nilai-nilai spiritual yang harus dilestarikan agar suatu organisasi tetap eksis. Di MA Darussalam nilai-nilai spiritual yang menjadi rutinitas diantaranya sholat 5 waktu berjamaah, sholat dhuha, kegiatan hadrah, dan sebagainya.

${ }^{23}$ Cecep Triatna, Perilaku Organisasi Dalam., 176.

Dirasah, Vol. 2, No. 2, Agustus 2019 


\section{Penutup}

Pada dasarnya, birokrasi hakikatnya adalah salah satu perangkat yang fungsinya untuk memudahkan pelayanan publik. Birokrasi pendidikan diharapkan dapat mempercepat peningkatan mutu pendidikan. Birokrasi dalam aspek pendidikan dapat dikatakan berhasil apabila terdapat sinergitas dan interaksi berdasarkan fungsinya masing-masing.

Perilaku organisasi adalah suatu studi yang menyangkut aspek-aspek tingkah laku manusia dalam suatu organisasi atau suatu kelompok tertentu. Ia meliputi aspek yang ditimbulkan dari pengaruh organisasi terhadap manusia demikian pula aspek yang ditimbulkan dari pengaruh manusia terhadap organisasi.

Sedangkan keberadaan budaya di dalam organisasi tidak bisa dilihat oleh mata, namun dapat dirasakan. Budaya organisasi itu bisa dirasakan melalui perilaku anggota di dalam organisasi itu sendiri. Kebudayaan tersebut memberikan pola, cara berfikir, merasa menanggapi dan menuntun para anggota di dalam organisasi.

\section{Daftar Pustaka}

Moorhead, Gregory dan Ricky W. Griffin, Perilaku Organisasi Manajemen Sumber Daya Manusia. Tangerang: Salemba Empat, 2010.

Triatna, Cecep. Perilaku Organisasi Dalam Pendidikan. Bandung: Remaja Rosdakarya. 2015.

Kurniadin, Didin dan Imam Mahalli. Manajemen Pendidikan, konsep dan prinsippengelolaan. Yokyakarta: ar Ruzz Media. 2012.

Syafarrudin. Manajemen Mutu Terpadu dalam Pendidikan. Jakarta: Grasindo. 2002

Wirawan. Budaya dan Iklim Organisasi. Jakarta: Salemba Barat. 2007.

Ruswadi, Uus. Landasan Pendidikan. Bandung: Insan Mandiri. 2008. 
Mulyasa. Manajemen Kependidikan Kepala Sekolah. Jakarta: Bumi Aksara. 2011.

Sagala, Syaiful. Administrasi Pendidikan Kontemporer. Bandung: CV Alfabeta. 2008.

Usman, Husaini. ManajemenTeori,Praktik, dan Riset Pendidikan. Jakarta: Bumi Aksara. 2009.

Sumidjo, Wahyo. Kepemimpinan Kepala Sekolah Tinjauan Teoritik dan Permasalahanya. Jakarta: PT Raja Grafindo Persada. 2003.

Toha, Miftah. Perilaku Organisasi Konsep Dasar dan Aplikasinya. Jakarta: PT Raja Grafindo Persada. 2007.

Wawancara dengan Walidi, Wakil Kepala Sekolah MA Darussalam, Depok Sleman Yokyakarta, pada tanggal 10 mei 2018.

Wawancara dengan Hamdani, Guru MA Darussalam Depok Yokyakarta, pada tanggal 10 Mei 2018.

Wawancara dengan Aziz Ahmad, Guru MA Darussalam Depok Yokyakarta, pada tanggal 10 mei 2018.

Copyright ( 2019 Journal Dirasah: Vol. 2, No. 2, Agustus 2019, p-ISSN: 2615-0212, e-ISSN;

2621-2838

Copyright rests with the authors

Copyright of Jurnal Dirasah is the property of Jurnal Dirasah and its content may not be copied or emailed to multiple sites or posted to a listserv without the copyright holder's express written permission. However, users may print, download, or email articles for individual use.

https://ejournal.iaifa.ac.id/index.php/dirasah

Dirasah, Vol. 2, No. 2, Agustus 2019 